\title{
Can Local News Prevent the Nationalization of Politics?
}

\author{
KUMAR RAMANATHAN | NORTHWESTERN UNIVERSITY
}

n 2017, the Federal Communications Commission (FCC), which regulates broadcast media in the United States, enacted several rule changes that were largely overlooked in mainstream political discourse. One change eliminated the requirement that television stations maintain a physical studio in the community where they are licensed, and two others made it easier for large media companies to own a larger share of the television broadcast market. These may seem at first glance to be regulatory changes of interest only to one industry, but political scientist Daniel J. Moskowitz argues in new research that they can significantly reshape our politics, by affecting the availability of local news broadcasts.

In his new article in the American Political Science Review, Moskowitz analyzes how the availability of local news on television shapes what researchers have called the "nationalization of elections" in the United States. Nationalization refers to the increasing importance of national parties and debates in shaping how ordinary people think about state and local elections. Prior research has observed how the outcomes of elections for members of Congress, governors, and other state and local officials have increasingly matched presidential election preferences across the country.

To study how the availability of local news affects the nationalization of elections, Moskowitz draws on a distinctive feature of television media markets. The boundaries of media markets

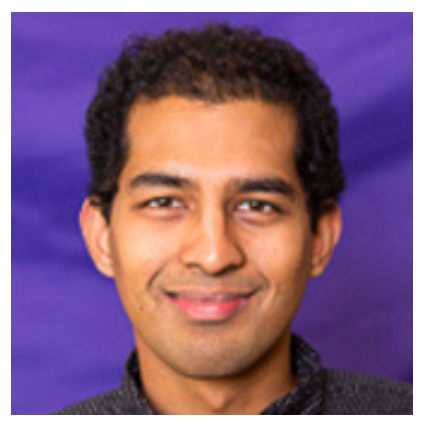

determine which television stations viewers can access. These markets often extend across state boundaries: for example, the Chicago media market covers many counties in Illinois, but also a few counties in Indiana. Meanwhile, many other Indiana counties fall into the Indianapolis media market. An-

Kumar Ramanathan is a PhD candidate in political science at Northwestern University and a doctoral fellow at the American Bar Foundation. He conducts research on racial inequality, law, and public policy in the United States.

In the APSA Public Scholarship Program, graduate students in political science produce summaries of new research in the American Political Science Review. This piece, written by Kumar Ramanathan, covers the article "Local News, Information, and the Nationalization of US Elections" by Daniel J. Moskowitz. The full article is available at: https://doi.org/10.1017/ $\underline{\text { s0003055420000829 }}$ alyzing the content of television news in each media market, Moskowitz shows that local news broadcasts focus on the state where most of their media market is located. This means that residents of Indiana counties in the Chicago media market receive local news broadcasts that discuss Illinois politics, whereas residents of those counties in the Indianapolis market receive more pertinent content about Indiana politics.

This feature of television media markets enables Moskowitz to assess whether access to local news affects people's political behavior. Drawing on surveys conducted in 2012 and 2016 with over 50,000 participants each, he compares those who have access to local news coverage about their own state (because they live in a state that comprises the majority of their media market) to those who receive local news broadcasts about neighboring states instead.

Moskowitz finds that access to local television news about one's own state has a clear effect on political knowledge. Individuals who had access to local television news were $9 \%$ more likely to recall their senator's party correctly and $11 \%$ more likely to recall their governor's party correctly. They were also significantly more likely to offer an evaluation of their senators and governors and to place these representatives on an ideological scale.

This increased knowledge about state politics also affects individuals' political behavior. One way to assess whether voters have a distinctive approach to state and local politics relative to national politics is to measure the level of "ticket-splitting." Ticket-splitting occurs when voters choose different parties for president and for state elected officials lower down on their ballot such as senator or governor. Moskowitz finds that access to local television news does increase the likelihood that a voter engages in ticket-splitting. Such voters are 2-3 percentage points more likely to cast a split ticket for senatorial elections and 4-5 percentage points more likely to do so for gubernatorial elections.

These findings underscore that access to local news helps voters stay informed about state politics. Local news can counteract the "nationalization" of politics, where partisan preferences about national politics shape how voters behave in state and local elections. Moskowitz argues that such nationalization can make state and local officials less accountable to their constituents, because voters' decisions are guided by national political issues and preferences rather than local officials' performance. To achieve democratic accountability in state and local government, therefore, preserving access to meaningful local news is essential. 